\title{
Razvoj komunikacijskih i timskih elemenata kompetencija za upravljanje projektima u virtualnom okruženju
}

\author{
Rebeka Danijela Vlahov Golomejić \\ Sveučilište u Zagrebu, Ekonomski fakultet, Hrvatska \\ e-mail:rvlahov@efzg.hr
}

\author{
Tomislav Rastovski \\ Visoko učilište Algebra, Zagreb, Hrvatska \\ e-mail: tomislav.rastovski@gmail.com
}

\author{
Damir Butković \\ Sveučilište u Osijeku, Ekonomski fakultet, Hrvatska \\ e-mail: butkovic.db@gmail.com
}

SAŽETAK Kako u suvremenom poslovnom okruženju sve veći broj organizacija temelji poslovanje na privremenim oblicima rada poput projekata, a s ciljem postizanja veće fleksibilnosti i boljih reakcija na impulse koji dolaze $s$ tržišta, posljedično raste i potražnja za kompetentnim pojedincima koji ne samo da imaju znanja o odgovarajućim alatima koje mogu koristiti već $i$ vještine i sposobnosti nošenja s izazovima i problemima koje takav način rada donosi. Također, recentna situacija te prelazak iz fizičkog u virtualno poslovno okruženje stavljaju dodatan naglasak na rad virtualnih projektnih timova, koji s jedne strane mogu korišstenjem novih tehnologija za komuniciranje i upravljanje napretkom projekta neometano raditi bez obzira na lokaciju na kojoj se u danom trenutku nalaze, dok se $s$ druge strane suočavaju s potpuno novom dinamikom rada, odnosa te suradnje među članovima tima. Stoga bi području upravljanju projektima, kao i razvoju potrebnih kompetencija kod pojedinaca, trebalo posvetiti značajnu pozornost već tijekom formalnog obrazovanja, a mlade najkasnije tijekom studija pripremati za tržište rada mijenjajući fokus $s$ učenja značajnih količina podataka na simuliranje stvarnih situacija i rad u timovima na projektima kako bi u sigurnom okruženju napredovali bez straha od pogreške i učili iz vlastitog iskustva. U ovom je radu na uzorku od 106 studenata završnih godina triju studija ispitana percepcija doprinosa formalne edukacije u virtualnom okruženju razvoju komunikacijskih i timskih elemenata kompetencija za upravljanje projektima, kao i izazova s kojima su se pritom suočavali, $s$ ciljem formiranja kvalitetne osnove za unaprjeđenje pristupa obrazovanju mladih u području u periodu koji slijedi.

Ključne riječi: elementi kompetencija, formalna edukacija, komunikacija, timski rad, upravljanje projektima, virtualno okruženje, virtualni timovi. 


\section{Uvod}

Više nego ikad prije, poslovno je okruženje karakterizirano brzim promjenama i neizvjesnostima, što uzrokuje porast broja organizacija kako u privatnom tako i u javnom sektoru rastućih, ali i zrelih industrija koje temelje svoje poslovanje na korištenju privremenih oblika rada poput projekata (Schoper i sur. 2018.; Thomas i Mengel, 2004.), s ciljem postizanja veće fleksibilnosti i boljih reakcija na impulse koji dolaze s tržišta, isporuke radnih paketa na ekonomičniji i kontroliraniji način te maksimalnog korištenja ograničenih ljudskih resursa za ispunjavanje zahtjeva kupaca i postizanje konkurentske prednosti (Bakker i sur., 2016.; Sydow, 2017.; Sołtysik, 2020.). Projekti tako ne predstavljaju samo alat za izvođenje složenih procesa već i stratešku opciju za organizacije koje djeluju u sve složenijim okolnostima, nužnu za opstanak, razvitak i poslovanje u cjelini (Gareis i Huemann, 2000.; Söderlund i Bredin, 2006.). Međutim, iako su varijable projekta i organizacije važne, pojedinačni su čimbenici i dalje ono što čini razliku u postizanju uspjeha, pa tako s porastom popularnosti upravljanja projektima raste i potražnja za pojedincima u ulozi voditelja projekata i članova projektnih timova, koji ne samo da imaju znanja o odgovarajućim alatima koje mogu koristiti već i vještine i sposobnosti nošenja s izazovima i problemima koje takav način rada donosi (Wong, 2007.; Ulrich i sur. 2008.; Bredin i Söderlund, 2013.). Stoga bi području upravljanju projektima, kao i razvoju potrebnih kompetencija za rješavanje teorijskih i praktičnih problema, trebalo posvetiti značajnu pozornost već tijekom formalnog obrazovanja, a mlade najkasnije tijekom studija pripremati za tržište rada mijenjajući fokus s učenja značajnih količina podataka koji nemaju praktične implikacije, na simuliranje stvarnih situacija i rad u timovima na projektima kako bi u sigurnom okruženju napredovali bez straha od pogreške i učili iz vlastitog iskustva (Turner i Huemann, 2000.; Christenson i Walker, 2004.). Također, kako bi se osigurao progresivan razvoj pojedinaca sposobnih za učenje, rad, suočavanje s povećanom dinamikom i učinkovito prilagođavanje promjenjivim okruženjima u kojima se projekti provode, formalni obrazovni programi trebali bi biti bazirani na međunarodno priznatim standardima kompetencija i zahtjevima za uspješno upravljanje projektima (Thomas i Mengel, 2008.; Ashleigh i sur. 2012.; Mozhei i Lukianov, 2019.).

Nadalje, recentna situacija s pandemijom bolesti COVID-19 te prelazak iz fizičkog u virtualno poslovno okruženje uvođenjem mjera socijalnog distanciranja i rada na daljinu uzrokuju dodatan pritisak na organizacije te zahtijevaju razvoj adaptivnih strategija, stavljajući naglasak na rad virtualnih projektnih timova (Zuofa i Ochieng, 2021.). Iako virtualni projektni timovi nisu nov koncept, ranije su formirani isključivo kako bi se olakšalo zajedničko stvaranje i inovacije među globalnim ili regionalnim stručnjacima koji nisu imali dovoljno vremena ili resursa za učestala putovanja da bi ispunili specijalizirane zadatke projekata koji su od njih zahtijevani. Danas, zahvaljujući novim uvjetima, mnoge organizacije koriste upravo takav način provedbe projekata, čak i u situacijama kada se zaposlenici nalaze u istoj državi ili gradu (Garro-Abarca, Palos-Sanchez i Aguayo-Camacho, 2021.), budući da korištenjem novih tehnologija za komuniciranje i upravljanje napretkom projekta mogu neometano nastaviti raditi na 
projektima te tako povećati produktivnost i smanjiti troškove za organizaciju. Međutim, to im donosi potpuno novu dinamiku rada, odnosa te suradnje među članovima tima (Oertig i Buergi, 2006.).

U nastavku rada bit će detaljnije razrađena uloga formalne edukacije u pripremi pojedinaca za nove radne uvjete, a zatim i prikazano empirijsko istraživanje percepcija doprinosa formalne edukacije u virtualnom okruženju razvoju komunikacijskih i timskih elemenata kompetencija za upravljanje projektima, kao i izazova koji su se pritom pojavljivali, što uključuje metodologiju istraživanja, analizu rezultata istraživanja i diskusiju te na kraju zaključak i popis literature korištene prilikom pisanja rada.

\section{Formalna edukacija i razvoj elemenata kompetencija u području upravljanja projektima}

Kako upravljanje projektima stječe popularnost u suvremenim organizacijama tako i postaje sve atraktivnije područje studija za studente, a predviđa se kako će $s$ vremenom interes za njime dodatno rasti zahvaljujući potrebama organizacija za specifičnim setom vještina, znanja i sposobnosti kod pojedinaca, kao i uvjetima rastuće konkurentnosti i ubrzanog razvoja (Thomas, Mengel i Andres, 2004.; PMI, 2018.). Stoga, da bi se udovoljilo toj potražnji, ali i učinilo formalnu edukaciju relevantnom za stvarno radno okruženje, upravljanje projektima počinje se uključivati kao značajna komponenta u nastavne planove i programe preddiplomskih, diplomskih i poslijediplomskih akademskih kvalifikacija (Crawford i sur., 2006.; Lee i sur. 2006.; Berggren i Söderlund, 2008.; Nijhuis, 2021.). Na obrazovnim je institucijama pritisak da budu upoznate $s$ najnovijim istraživačkim nalazima, da provode istraživanja u području i postanu lideri u razvoju struke (Berggren i Söderlund, 2008.) te da osiguraju da studente educiraju kompetentni i certificirani stručnjaci kako bi im pomogli da postanu proaktivni rješavači problema i kritički mislioci, a ne samo primatelji informacija (Ojiako, 2011.; Mozhei i Lukianov, 2019.).

Budući da projekte obično karakteriziraju jedinstvenost, nesigurnost i složenost, to nastavu iz upravljanja projektima čini izazovnijom, jer iako su pojmovi i koncepti lako dostupni i mogu se podučavati na izravan način, alati i tehnike za njihovu primjenu u projektima moraju se isprobati na praktičnim primjerima kako bi imali značaj u procesu učenja (Abernethy, Piegari i Reichgelt, 2007.; Hussein, 2015.). Osim toga, dodatna pažnja treba se posvetiti i metodama poučavanja, kombinirajući tradicionalne (teorijski inputi i rasprave na temelju kvalitetne literature) i moderne (studije slučaja, zajednička iskustva, simulacije i igre) pristupe kako bi se osiguralo stjecanje ne samo specifičnih i tehničkih znanja već i razvoj mekih vještina kod studenata (Crawford i Pollack, 2006.; Pant i Baroudi, 2008.; Mozhei i Lukianov, 2019.). Turner i Huemann (2000.) također naglašavaju važnost dodavanja još nekoliko aspekata koji su ključni za stvaranje okruženja iz kojeg će proizaći stručnjaci u području. Oni uključuju: 1) globalnu standardizaciju (u načinima isporuke i podučavanju znanja), ali imajući na 
umu kulturne razlike i specifičnosti, 2) odgovarajuće strukture obrazovnog procesa usklađene sa svim interesnim skupinama, 3) praktičnu važnost predmeta koji se uči za razvijanje kompetencija usklađenih s individualnim i poslovnim potrebama, 4) pedagoške potrebe i standarde kvalitete sveučilišne nastave te 5) osiguranje potpore poslovnih i profesionalnih organizacija obrazovanju za upravljanje projektima i razvoju profesionalaca u tom području, kao i prepoznavanje profesije i odgovarajućih karijernih putova (za potrebe ovog rada fokus je stavljen na međunarodnu organizaciju koja okuplja udruženja za upravljanje projektima - International Project Management Association (IPMA), koja djeluje u 72 zemlje putem svojih članica te u suradnji sa stručnjacima, organizacijama, vladinim agencijama i sveučilištima kontinuirano radi na razvoju potrebnih individualnih kompetencija za upravljanje projektima, kao i na prepoznavanju i povezivanju visokokvalitetne edukacije za njihov razvoj u globalnu mrežu IPMA Education \& Training Registration System (IPMA REG)).

U konačnici, formalna edukacija u području upravljanja projektima treba osiguravati studentima i određenu dozu realnosti kako bi se pripremili za izazove koji ih očekuju, pri čemu u trenutnim okolnostima veliku ulogu ima obrazovanje u virtualnom okruženju i rad u virtualnim projektnim timovima, što se pokazalo kao „prirodno“ rješenje s obzirom na to da izazovi tijekom procesa učenja i razvoja kompetencija nalikuju onima u upravljanju projektima u složenim i nesigurnim okruženjima (Thomas i Mengel, 2008.; Gadille, i Caraguel, 2021.).

\section{Metodologija istraživanja}

$S$ ciljem dobivanja uvida u način rada studenata u virtualnom okruženju, izazove rada s kojima se susreću i načinima njihova rješavanja, kao i ključne elemente kompetencija za upravljanje projektima koji su tijekom rada unaprijeđeni, s posebnim naglaskom na komunikaciju i timski rad (ili razloge zašto nisu unaprijeđeni), autori rada provode kombinaciju kvantitativnog i kvalitativnog empirijskog istraživanja na populaciji studenata završnih godina koji su pohađali kolegije za upravljanje projektima registrirane unutar međunarodno priznatog sustava kvalitete za razvoj kompetencija iz područja upravljanja projektima (IPMA REG) na Ekonomskom fakultetu Sveučilišta u Zagrebu, Visokom učilištu Algebra i Veleučilištu Baltazar Zaprešić. Istraživanje je obuhvaćalo studente koji su do 2020. godine nastavu pohađali uživo u dvoranama i radili na projektima u klasičnim timovima, dok su od ožujka 2020. virtualno pohađali kolegije za upravljanje projektima, te radili u virtualnim projektnim timovima, pod vodstvom profesora i suradnika iz prakse. Na taj su način stekli dovoljno iskustva u oba načina rada na projektima, te su ih mogli adekvatno usporediti, kao i iznijeti svoje stavove. Studenti su sudjelovali u nastavi jedan semestar (sudjelovanje je bilo obvezno). Nastava je uključivala predavanje profesora/predavača na kolegiju (koji i sami imaju iskustvo u upravljanju projektima), predavanja gostujućih stručnjaka iz prakse, koji su im objašnjavali temeljne koncepte na primjerima iz vlastitih poduzeća ili profesionalnih asocijacija, te rada u projektnim timovima. Na početku nastave studenti su podijeljeni 
u projektne timove slučajnom raspodjelom, s mogućnošću samostalne podjele uloga unutar tima, te su tijekom cijelog razdoblja radili na simulacijama stvarnih projekata.

Primarni podaci prikupljeni su metodom anketnog upitnika tijekom ljetnog semestra akademske godine 2019./2020. te zimskog semestra akademske godine 2020./2021. Anketni upitnik sastojao se od 12 pitanja zatvorenog i 12 pitanja otvorenog tipa, podijeljenih u nekoliko tematskih cjelina: formiranje projektnih timova i raspodjela uloga studenata, izazovi rada u virtualnom projektnom okruženju i načini njihova rješavanja, komunikacija i timski rad. Anketni je upitnik distribuiran elektronskim pozivom za sudjelovanje te je procijenjeno vrijeme za njegovo popunjavanje bilo između 25 i 30 minuta. Tijekom istraživanja poštivana su sva etička načela vezana uz provedbu u smislu anonimnosti i dobrovoljnosti te prava na izražavanje vlastitih mišljenja i prava na odustajanje. Prikupljeno je 106 ispravno popunjenih anketnih upitnika, što čini $76,26 \%$ od ukupnog broja studenata na promatranim kolegijima.

Prikupljeni podaci organizirani su, kodirani i analizirani pomoću metode utemeljene teorije (Corbin i Strauss, 2008.), te su identificirana tri ključnih područja, odnosno koda: izazovi rada u virtualnom okruženju, razvoj elementa kompetencije komunikacije za upravljanje projektima i razvoj elementa kompetencije timskog rada za upravljanje projektima, predstavljena u nastavku rada i prikazana u tablicama radi preglednosti te popraćena odgovarajućim citatima navedenima u fusnotama i označenima šiframa generalne prirode kako bi bila sačuvana anonimnost sudionika istraživanja.

\section{Rezultati istraživanja i diskusija}

U istraživanju je sudjelovao podjednak broj studenata sa svake obrazovne institucije, odnosno 40 studenata Visokog učilišta Algebra, 37 studenata Veleučilišta Baltazar Zaprešić te 29 studenata Ekonomskog fakulteta Sveučilišta u Zagrebu, od čega 53,73\% ženskog i 46,27\% muškog spola (tablica 1).

Tablica 1.

Raspodjela studenata u uzorku po instituciji i spolu

\begin{tabular}{|l|c|c|c|c|c|c|c|}
\hline $\begin{array}{c}\text { Spol/ } \\
\text { institucija }\end{array}$ & \multicolumn{2}{|c|}{$\begin{array}{c}\text { Ekonomski fakultet } \\
\text { Sveučilišta u Zagrebu } \\
\mathbf{( N = 2 9 )}\end{array}$} & \multicolumn{2}{|c|}{$\begin{array}{c}\text { Visoko učilište Algebra } \\
\mathbf{( N = 4 1 )}\end{array}$} & $\begin{array}{c}\text { Veleučilište Baltazar } \\
\text { Zaprešić } \\
\mathbf{( N = 3 7 )}\end{array}$ & $\begin{array}{c}\text { Ukupno } \\
\mathbf{( N = 1 0 6 )}\end{array}$ \\
\hline Muški & 5 & $17,24 \%$ & 29 & $72,50 \%$ & 15 & $40,54 \%$ & $\mathbf{4 6 , 2 7 \%}$ \\
\hline Ženski & 24 & $82,76 \%$ & 11 & $27,50 \%$ & 22 & $59,46 \%$ & $\mathbf{5 3 , 7 3 \%}$ \\
\hline
\end{tabular}




\subsection{Izazovi rada u virtualnom okruženju}

Studenti navode kako su se tijekom rada u virtualnom okruženju susretali s tehničkim izazovima, izazovima rada s timom te osobnim izazovima (tablica 2).

Tablica 2.

Izazovi rada u virtualnom okruženju

\begin{tabular}{|c|c|}
\hline Kategorija izazova & Aspekti koje uključuje \\
\hline Tehnički izazovi & $\begin{array}{ll}\text { - } & \text { loša internetska veza } \\
\text { - } & \text { neadekvatna i/ili nefunkcionalna informatička oprema } \\
\text { - } & \text { sudjelovanje u nastavi u neprikladnom okruženju }\end{array}$ \\
\hline Izazovi rada s timom & $\begin{array}{l}\text { - } \quad \text { usklađivanje vremenskog rasporeda / nedostupnost članova tima } \\
\text { - } \quad \text { motivacija članova tima za rad } \\
\text { - } \quad \text { nerazumijevanje među članovima tima i neprihvaćanje tuđih ideja } \\
\text { - } \\
\text { sukobi među članovima tima }\end{array}$ \\
\hline Osobni izazovi & nedovoljna informatička pismenost \\
\hline
\end{tabular}

Unutar kategorije tehničkih izazova, više od polovice studenata navodi kako se tijekom rada na projektu suočilo s lošom internetskom vezom, bilo vlastitom ili kod kolega $^{1,2}$, što je u danom trenutku otežalo suradnju među članovima tima, međutim bez značajnih posljedica na izvedbu projekta, budući da su se snalazili korištenjem dodatnih oblika komunikacije i angažmanom oko dijelova zadataka koje su trebali obaviti oni koji u tom trenutku nisu bili u mogućnosti ${ }^{3,4}$ Osim toga, pojedini studenti navode i neadekvatnu i/ili nefunkcionalnu informatičku opremu, zbog čega je znalo dolaziti do otežane komunikacije i provedbe zadataka ${ }^{5,6}$, kao i sudjelovanje u nastavi u neprikladnom okruženju poput automobila, parkova ili tijekom radnog vremena iz

${ }^{1}$ A15 "Često su nam se događale situacije kada bi neka od nas izgubila signal ili imala lošu internetsku vezu, ali smo ih relativno brzo riješile i nisu utjecale na izradu samog projekta.“

2 B39 "Loša veza mi je često bila problem, pričam i ne skužim da me ne čuju pa moram utvrditi otkud moram ponavljati.“

3 B7 “[...] najviše problema je bilo tehničke prirode, npr. loša internetska veza zbog koje bi nas izbacivalo iz vježbi/predavanja, ali to smo riješili komunikacijom $s$ tim osobama telefonski, uputili bismo ih o čemu je bilo riječ tijekom vremena koje su propustili pa bi nastavili normalno raditi dalje."

${ }^{4}$ C21 "Uglavnom nije bilo nikakvih problema. MS Teams je u nekim slučajevima trebalo ponovno pokrenuti zbog loše internetske veze, ali ne bih rekao da je to utjecalo na kvalitetu rada s obzirom da smo se uvijek nekako snašli i uskočili gdje je trebalo."

5 A21 "Pojedini članovi tima i ja osobno tijekom semestra imali smo problema s osobnim računalima koja nisu radila kako treba što je znalo usporiti cijeli proces, no zajedničkim dogovorom uvijek se pronašlo alternativno rješenje.“

6 C25 "Tijekom predavanja jedan kolega nije htio upaliti mikrofon i kao razlog je naveo da ga nema, a dobro svi znamo da u današnje vrijeme to nije moguće, naravno i kao alternativa nam uvijek može poslužiti mobitel." 
ureda koje dijele $s$ kolegama te gdje ne mogu slobodno razgovarati, što im je u ovom vidu nastave bilo omogućeno ${ }^{7,8}$.

Kao glavne izazove povezane s radom projektnog tima, studenti navode problem uskladivanja vremenskih rasporeda izvan vremena nastave kako bi radili na projektnim zadacima s obzirom na poslovne i druge obveze ${ }^{9,10,11}$. Osim toga, pojavili su se i problemi $s$ motivacijom pojedinih članova tima, što je bilo vidljivo iz neodgovaranja na poruke te nedovoljnog ulaganja vremena i truda u izradu zadataka ${ }^{12}$, nepoštivanja rokova, povremenog nerazumijevana među članovima tima i otežane komunikacije ${ }^{13}$ te neprihvaćanja tuđih ideja ${ }^{14}$, što proizlazi iz odnosa pojedinca prema drugima i u pojedinim slučajevima rezultira sukobom. Proizašli sukobi rješavani su otvorenom komunikacijom među voditeljem projekta i članovima tima, kompromisom i potporom članovima kojima je bila potrebna pomoć, međutim u tri slučaja sukob nije riješen, te je došlo do zamjene voditelja projekta, potpunog reformiranja tima, odnosno odlaska jedne kolegice iz tima, nakon čega su timovi nastavili uspješno surađivati do predaje projektnog zadatka.

Nekolicina studenata kao osobni izazov vidi i nedovoljnu informatičku pismenost, bilo vlastitu ili kod kolega iz tima, što otežava suradnju i usporava tim s obzirom na to da osim specijaliziranih IT rješenja za praćenje napretka projekta, o kojima se uči tijekom kolegija, znanja o ostalim korištenim alatima studenti su trebali steći na ranijim razinama studija ili učeći samostalno kako bi održavali korak s kolegama.

7 B22 "Nisu svi članovi sudjelovali od doma, npr. u mom timu ih je nekoliko radilo za vrijeme nastave i javljali su se iz ureda pa nisu htjeli upaliti kameru i pričati na mikrofon, već bi pisali poruke što nije bilo ok. Smatram da je jednostavnije i efektivnije pokušati naginjati obliku komunikacije kao da uživo zajedno radimo."

8 B35 "Pojedini članovi tima nisu shvaćali ozbiljno sastanke pa su se javljali mobitelom iz raznih situacija (trgovina, park, šetnja, auto...).“

9 A2 "Najveći izazov je bio uskladiti vremenske rasporede svih članova (zbog drugih kolegija i poslovnih obveza). Također, budući da komunikacija na daljinu to dopušta, često se dešavalo ignoriranje poruka i odgađanje odgovaranja na iste od ostalih članova."

10 C5 "Teška organizacija vremena u smislu tko kada može. Većina članova tima radi ili ima druge obveze tijekom tjedna pa je ponekad bilo teško naći vrijeme koje svima odgovara (van nastave).“

11 B34 "Uglavnom je bilo teško uskladiti vrijeme sastanka. Zbog posla smo morali dogovarati u večernjim satima kad su svi već bili pomalo umorni."

12 B27 “[...] Izazov je bio održati motivaciju i fokus za kontinuiranoj i kvalitetnoj izradi projekata, kao i fokus na zadatak. Zbog manjka fizičkog kontakta ostali članovi mogu raditi šta god žele i praviti se da sudjeluju, do trenutka kad nešto trebaju predati. A onda imamo problem.“

13 B40 "Puno teže je komunicirati s drugim ljudima kad ih ne vidiš nego samo čuješ. Kad npr. u isto vrijeme počne pričati više ljudi odjednom pa svi stanu, pa čekaju tko će prvi početi (to se ne događa na sastancima uživo jer vidiš svakog pa je lakše komunicirati).“

14 C28 “[...] a najgore od svega je što je kolega komunicirao totalno neprofesionalno (bezobrazan i napadački stav), nije imao vlastitih ideja i prijedloga, no cijelo vrijeme je podcjenjivao tuđe." 
I na kraju, trećina studenata, iako nije naišla na značajne izazove i poteškoće, preferira rad u klasičnim timovima u odnosu na virtualne timove, navodeći kao najčešći razlog nedostatak socijalne komponente ${ }^{15,16}$ i povezanosti među članovima tima ${ }^{17}$.

\subsection{Razvoj elementa kompetencije komunikacije za upravljanje projektima}

Studenti su sudjelovali u nastavi jednom do dva puta tjedno putem službeno propisanih platformi za izvođenje nastave: Zoom (Ekonomski fakultet Zagreb), AdobeConnect (Visoko učilište Algebra) i MsTeams (Veleučilište Baltazar Zaprešić), dok su za pohranu dokumenata koristili Google Drive. Ubrzo nakon početka rada na projektu većina je timova počela koristiti i neformalne alate za komunikaciju izvan vremena nastave, i to WhatsApp, Viber i Discord, na kojima su kreirali grupe za razgovor.

Od ukupnog broja studenata, njih $88,68 \%$ smatra kako su unaprijedili komunikaciju tijekom rada na projektu u virtualnom okruženju, s naglaskom na: vještinu prezentiranja, vještinu slušanja i postavljanja pitanja, interakciju s ljudima koje nisu prethodno poznavali te izgradnju kohezije i povjerenja među članovima virtualnog tima (tablica 3).

Tablica 3.

Razvoj elementa kompetencije komunikacije za upravljanje projektima

\begin{tabular}{|c|c|}
\hline Ključni pokazatelj kompetencije & Aspekti koje uključuje \\
\hline Vještina prezentiranja & $\begin{array}{l}\text { - } \\
\text { - } \quad \text { prezentiranje sebe i zagovaranje svojih ideja i stavova } \\
\text { - } \\
\text { prenošenje poruke u novom okruženju u kojem postoji nedostatak } \\
\text { neverbalne komunikacije }\end{array}$ \\
\hline Aktivno slušanje i postavljanje pitanja & $\begin{array}{l}\text { - } \quad \text { fokus na ono što drugi govore } \\
\text { - } \quad \text { postavljanje relevantnih pitanja profesorima i kolegama } \\
\text { aktivno sudjelovanje u nastavi i komunikacija povezana s } \\
\text { projektom }\end{array}$ \\
\hline Interakcija s članovima tima & $\begin{array}{l}\text { - } \quad \text { upoznavanje članova tima } \\
\text { otvorena komunikacija s ljudima koje ranije nisu poznavali ili s } \\
\text { kojima nisu radili }\end{array}$ \\
\hline
\end{tabular}

15 A14 "Mišljenja sam da nam je suradnja bila odlična s obzirom koliko je to moguće u online svijetu i u danim okolnostima. Međutim, žao mi je što se nismo mogli vidjeti uživo da se bolje upoznamo, ali to ćemo svakako učiniti čim se stvore uvjeti jer nam je jako nedostajao taj dio.“

16 A3 "Zasigurno da je falilo komunikacije uživo. Mnogo puta smo rekle kako bismo dale sve da možemo uživo prokomentirati sve vezano za projekt, a nakon toga i nastaviti druženje međusobno. Naprosto smo si "kliknule"."

17 A29 „Pa mislim da bi sve bolje funkcioniralo da smo se upoznali uživo jer se mi kao članovi tima ne znamo otprije i nismo se uspjeli povezati kako bi to vjerojatno bilo da smo bile u dvorani.“ 
U kontekstu razvoja vještine prezentiranja, studenti tijekom rada na projektu u virtualnom okruženju percipiraju pozitivan pomak u vještini prezentiranja sebe, svojih vještina i stavova ${ }^{18}$, kao i predstavljanju i zagovaranju projektnih ideja pred članovima projektnog tima, profesorima, suradnicima u nastavi te ostalim kolegama iz grupe $\mathrm{e}^{19}$, ${ }^{20}$. Osim toga, spominju i smanjenje razine ili potpuno oslobođenje od treme ${ }^{21}$ te rast samopouzdanja tijekom prezentiranja ${ }^{22}$.

Nadalje, većina studenata navodi kako su se tijekom nastave osjećali puno slobodnije nego u dvorani iznositi svoja mišljenja, postavljati profesorima pitanja i sudjelovati u diskusijama jer nisu osjećali pritisak ili neodobravanje kolega ${ }^{23,24}$. Također, kao vrlo važno spominju i unaprjeđenje vještine aktivnog slušanja, bolju koncentraciju te promišljanje o onome što je rečeno ${ }^{25}$.

U pogledu interakcije s članovima tima, posebno je istaknuto upoznavanje s članovima tima jer nisu znali što očekivati ${ }^{26,27}$. Do tada su tijekom studija sami birali s kim

18

C20 "Definitivno sam poboljšsala prezentacijske vještine, slobodnije sam predstavila svoje snage i interese ostalima, te branila svoje ideje u diskusijama. Zbog tog ishoda mi je vrlo drago jer sam bila svjesna da na tome moram poraditi."

19 A7 "Više puta sam imala priliku prezentirati dijelove našeg projekta profesorima u zasebnoj Zoom sobi, i odgovarati na njihova pitanja, a i jednom pred svima u zajedničkoj Zoom sobi i to mi je nekako postalo normalno."

20 C29 "Morala sam se prilagoditi i naučiti prezentirati svoje ideje na potpuno novi način s obzirom da je isključivo verbalna komunikacija bila u pitanju, i često ne vidiš reakcije drugih jer nemaju upaljenu kameru."

21 B20 "Puno sam se lakše fokusirala na ono što trebam reći u prezentacijama pred profesorima jer mi je bio manji pritisak i stres kada se komunikacija odvijala u online okruženju."

22 B32" [...] osjećala sam se sigurnije i naraslo mi je samopouzdanje u prezentiranju vlastitih stavova što će mi svakako biti korisno i kad se vratim u stvarno okruženje."

23 B21 "Počela sam postavljati pitanja i sudjelovati u raspravama tijekom nastave. Definitivno je lakše probiti led kada smo iza malih ekrana."

24 C38 "Bilo mi je puno ugodnije aktivno sudjelovati i na predavanjima i na seminarima jer je puno manje iskazana dominacija pojedinih ljudi iz grupe nego u fizičkoj prisutnosti.”

25 A16 "Unaprijedio sam slušanje. Slušati nije lagano, a što sam se više koncentrirao, to mi je bilo lakše uspostaviti komunikaciju."

26 A24 "Definitivno smatram da sam unaprijedila komunikacijske vještine s ljudima koje prethodno nisam poznavala jer mi je to bio jedan od najvećih strahova tko će se naći u mome timu te hoću li uspješno moći surađivati s njima, no sve se tako lijepo raspodijelilo i ta sumnja je nestala odmah nakon prvog sastanka kada smo se sve članice tima dobro upoznale..."

27 A3 "Komunikacija s ljudima koje nisam prethodno poznavala kao najveći aspekt. Na početku je bilo neizvjesno s kim ću biti u timu, kako će to biti, kako ćemo se slagati... ljudi su skloni polariziranju i osobno sam bila više na pesimističnoj strani, ali se ispostavilo da su članice odlične i kvalitetne cure koje bih osobno voljela upoznati." 
će raditi i gotovo su uvijek birali iste ljude. Tijekom formiranja projektnih timova slučajnom raspodjelom, iako su se studenti međusobno poznavali s prethodnih kolegija ili studija u cjelini, njih $41,51 \%$ navodi kako nikada prije nisu imali prilike raditi zajedno, njih $31,13 \%$ radilo je $s$ jednom osobom, a $27,36 \%$ s više ljudi s kojima su raspoređeni u projektni tim, na zadacima ili projektima na drugim kolegijima. Kao drugi važan element navode da su naučili kako uspostaviti kontakt s ljudima s kojima komuniciraju po prvi put, a zatim i uspješno verbalno komunicirati tijekom odrade projektnih zadataka ${ }^{28}$.

Studenti u ulozi voditelja projekta naglašavaju dodatno i da su naučili davati pozitivne i negativne povratne informacije, nositi se $s$,teškim“ članovima tima, rješavati sukobe, motivirati članove tima i stvarati ugodno radno okruženje u kojem se potiče otvorena komunikacija, poštuju mišljenja drugih i osigurava međusobno razumijevanje, kako bi u konačnici uspostavili dobar timski rad i osigurali da svi projektni dijelovi budu napravljeni na najbolji mogući način u definiranim vremenskim rokovima.

Studenti koji smatraju da nisu unaprijedili svoje komunikacijske vještine navode kako su ekstroverti te da bi jednako i na isti način komunicirali uživo kao što su to činili u internetskom okruženju, preferiraju komunikaciju s ljudima uživo, smatraju da se s ljudima moguće i bolje sporazumjeti i bolje povezati u osobnoj komunikaciji te da je ključna komponenta koja je nedostajala neverbalna komunikacija, a ona čini vrlo važan dio komunikacije.

\subsection{Razvoj elementa kompetencije timskog rada za upravljanje projektima}

Iako su projektni timovi formirani slučajnom raspodjelom, studenti su imali slobodu samostalno odrediti uloge i zadatke, kao i upravljati odnosima. Profesori i suradnici u nastavi uključivali su se u rješavanje problema samo ukoliko je to bilo zatraženo, što se dogodilo u jednom slučaju kada je tim u potpunosti reformiran te članovi raspoređeni u druge timove.

Od ukupnog broja studenata, njih 91,51\% smatra kako su unaprijedili timski rad tijekom rada na projektu u virtualnom okruženju, s naglaskom na: formiranje tima, suradnju između članova tima te snalažljivost (tablica 4).

\footnotetext{
28 C24 “[...] Bilo je izazovno susresti se sa situacijom gdje iznosiš svoje ideje i mišljenje osobama koje prethodno nisi upoznao, moraš ih dobro argumentirati, ali i biti svjestan da se ostali članovi možda neće složiti, biti spreman prihvatiti kritiku i komunikacijom doći do kompromisa, odnosno najboljeg rješenja. Shvatila sam da se komunikacija u online obliku može održati na visokoj i uspješnoj razini, te sam se naučila lijepo verbalno izražavati."
} 
Tablica 4.

Razvoj elementa kompetencije timskog rada za upravljanje projektima

\begin{tabular}{|l|l|l|}
\hline \multicolumn{1}{|c|}{ Ključni pokazatelj kompetencije } & \multicolumn{1}{c|}{ Aspekti koje uključuje } \\
\hline Formiranje tima & $\bullet$ & određivanje timskih uloga na temelju interesa i kompetencija \\
\hline Suradnja među članovima tima & $\bullet$ & $\begin{array}{l}\text { druženje tijekom i izvan nastave povezano s projektnom i neformalno } \\
\text { stvaranje timske kohezije i povjerenja }\end{array}$ \\
\hline Snalažljivost & $\bullet$ & iznalaženje kreativnih načina za rješavanje zadataka i problema \\
\hline
\end{tabular}

Iako u radu s prijašnjim timovima nisu previše pozornosti posvećivali upoznavanju članova i razumijevanju njihovih kompetencija, što možebitno proizlazi iz činjenice da su većinu projekata tijekom studija radili s istim ljudima, ovaj su put početne sate zajedničkog rada posvetili međusobnom upoznavanju, a nakon što je definirana projektna ideja, i podjeli timskih uloga. Ta je odluka bazirana na informacijama koje su članovi prezentirali o sebi, svojim interesima i kompetencijama te usklađivana kako su se novi zadaci pojavljivali tijekom provedbe projekta. ${ }^{29}$ Voditelj tima određen je demokratski te je samo u jednom slučaju zamijenjen zbog načina upravljanja timom $s$ kojim se ostali članovi tima nisu slagali ${ }^{30}$.

Također, suradnja je postajala bolja što su duže radili zajedno te počeli komunicirati i na osobnoj i neformalnoj razini izvan vremena nastave. Studenti navode kako su se tijekom vremena međusobno bolje upoznali, naučili kako efikasnije planirati i koordinirati aktivnosti te biti fleksibilniji i kreativniji u reakcijama, što je povećalo ne samo timsku koheziju i povjerenje ${ }^{31,32}$ već i snalažljivost u odradi različitih zadataka i rješavanju problema na koje su nailazili ${ }^{33}$.

29 A19 "Prvo smo u razgovoru pokušali saznati koje su nam kompetencije zajedničke, a zatim i u čemu je svaka osoba posebno dobra i jedinstvena. Zatim smo rasporedili zadatke unutar tima po preferencijama. Osim toga, pričali smo i o razini motivacije i ambicije za ovaj projektni zadatak."

30 B34 "PM je bio malo agresivan i postavljao se kao šef, pa smo ga morali zamijeniti. Nakon toga je sve bilo ok."

31 A5 "Vjerovali smo jedni drugima i vrlo dobro se slagali u većini slučajeva. Otprilike smo imali podjednaku količinu zadataka, u nekima je svatko morao "potegnuti” više.

32 A21 "Jedan član tima i projektni menadžer su često preuzimali vodeću ulogu i delegirali zadatke ostatku tima. Tim se međusobno upotpunjavao, ako jedan tjedan netko nije mogao biti prisutan cijelo vrijeme ili je imao tehničkih poteškoća, ostatak tima bi uskočio i odradio i njegov/njezin dio. Gotovo cijeli semestar je vladala opuštena atmosfera, a zajednička ideja i timski duh stvorili su određenu dozu povjerenja među članovima tima."

33 C38 "Rad na projektu mi je donio četiri potpuno nove osobe koje sam upoznavao tijekom cijelog semestra. Do kraja smo se jako povezali, super smo surađivali i svaki problem iskoristili da još više unaprijedimo svoj proizvod koji je na kraju ispao daleko bolji od očekivanja. [...] Razmišljamo da prijavimo naš projekt za sredstva iz Europskih fondova kad se natječaj koji smo koristili kao predložak na nastavi ponovno otvori i nastavimo raditi zajedno." 
Studenti u ulozi voditelja projekta naglašavaju dodatno da su naučili i kako definirati radne pakete i delegirati ih pravim članovima tima, donositi pravovremene odluke, prepoznavati pogreške i učiti iz njih te osnaživati članove tima da preuzmu inicijativu i proaktivnim pristupom poslu dodatno doprinesu kako kvaliteti procesa provedbe projekta tako i kvaliteti finalnog projektnog proizvoda.

Studenti koji smatraju da nisu unaprijedili svoje vještine timskog rada navode da bi rad uživo bio puno dinamičniji i kompetitivniji, a pristup radu ozbiljniji. Osim toga, dodaju i da im bez obzira na sve prednosti rad putem interneta ne može zamijeniti rad s ljudima u dvorani, a u nekim se slučajevima nisu ni osjećali kao članovi tima.

\section{Zaključak}

Kako upravljanje projektima dobiva na značaju u poslovanju suvremenih organizacija tako raste i potreba za kompetentnim voditeljima projekata i članovima projektnih timova koji će projektima upravljati na profesionalan način, a formalno obrazovanje u tom pogledu ima ključnu ulogu. Obrazovni modeli stoga bi trebali podržavati i poticati kontinuirane promjene, kreativno i kritičko promišljanje, samoorganizirano umrežavanje i međusobno osnaživanje, virtualnu komunikaciju te suočavanje s neizvjesnošću i raznim referentnim okvirima. Provedeno empirijsko istraživanje generira inicijalne spoznaje koje bi mogle biti zanimljive široj grupi interesnih skupina u hrvatskom sustavu obrazovanja u području upravljanja projektima te daju dobru osnovu za unaprjeđenje sustava obrazovanja mladih s ciljem razvoja elemenata kompetencija za upravljanje projektima. Buduća istraživanja trebala bi se proširiti i na poslodavce kako bi se dobio uvid u potrebne kompetencije, iskustvo rada s mladima koji izlaze $s$ fakulteta te zadovoljstvo razinom njihovih znanja, vještina i sposobnosti u području upravljanja projektima. $\mathrm{Na}$ taj bi način bilo moguće prilagoditi formalne obrazovne programe potrebama različitih tržišnih segmenata te ih kontinuirano revidirati i poboljšavati kako bi kod mladih bile razvijane upravo one kompetencije za upravljanje projektima koje će im biti najpotrebnije. 


\section{Literatura}

1. Abernethy, K.; Piegari, G. and Reichgelt, H. (2007). Teaching project management: an experiential approach. Journal of Computing Sciences in Colleges, 22 (3): 198-205.

2. Ashleigh, M.; Ojiako, U.; Chipulu, M.; Wang, J. K. (2012). Critical learning themes in project management education: Implications for blended learning. International Journal of Project Management, 30 (2): 153-161.

3. Bakker, R. M.; DeFillippi, R.; Schwab, A.; Sydow, J. (2016). Temporary organizing: Promises, processes, problems. Organization Studies, 37: 1703-1719.

4. Berggren, C. and Söderlund, J. (2008). Rethinking project management education: Social twists and knowledge co-production. International Journal of Project Management, 26 (3): 286-296.

5. Bredin, K. and Söderlund, J. (2013). Project managers and career models: An exploratory comparative study. International Journal of Project Management, 31: 889-902.

6. Christenson, D. and Walker, D. H. (2004). Understanding the role of "vision" in project success. Project Management Journal, 35 (3): 39-52.

7. Corbin, J. and Strauss, A. (2008). Basics of qualitative research: Techniques and procedures for developing grounded theory. Thousand Oaks: Sage Publications

8. Crawford L. and Pollack J. (2004). Hard and soft projects: a framework for analysis. International Journal of Project Management, 22 (8): 645-653.

9. Crawford L.; Morris P.; Thomas J.; Winter M. (2006). Practitioner development: from trained technicians to reflective practitioners. International Journal of Project Management, 24 (8): 722-733.

10. Gadille, M. and Caraguel, V. (2020). Building the new millenium skills for project management in higher education: how virtual worlds can help teachers and students?. Proceedings of the 12th annual International Conference on Education and New Learning Technologies.

11. Gareis, R. and Huemann, M. (2000). Project Management Competencies in the Project-oriented Organisation, in: Turner, J. R. and Simister, S. J. (Eds.). The Gower Handbook of Project Management. New York: Routledge.

12. Garro-Abarca, V.; Palos-Sanchez, P. and Aguayo-Camacho, M. (2021). Virtual Teams in Times of Pandemic: Factors That Influence Performance. Frontiers in Psychology, 12: 232.

13. Hussein, B. (2015). A blended learning approach to teaching project management: A model for active participation and involvement: Insights from Norway, Education Sciences, 5 (2): 104-125.

14. Lee, H.; Bonk, C. J.; Magjuka, R. J.; Su, B.; Liu, X. (2006). Understanding the dimensions of virtual teams. International Journal of E-learning, 5 (4): 507-523.

15. Mozhei, K. A. i Lukianov, D. V. (2019). Contemporary approaches in project management education in Belarus. Proceedings of XVIII international scientificexpert conference, 166-171. 
16. Nijhuis, S. A. (2021). Somebody Has to Teach Them, But What? Moving Towards Sustainable Teaching of Project Management, in: Cuevas, R.; Bodea, C. N. and Torres-Lima, P. (Eds.). Research on Project, Programme and Portfolio Management. Cham: Springer, 261-271.

17. Oertig, M. and Buergi, T. (2006). The challenges of managing cross-cultural virtual project teams. Team Performance Management: An International Journal, $12(1 / 2): 23-30$.

18. Ojiako, U.; Ashleigh, M.; Chipulu, M.; Maguire, S. (2011). Learning and teaching challenges in project management. International Journal of Project Management, 29 (3): 268-278.

19. Pant, I. and Baroudi, B. (2008). Project management education: The human skills imperative. International Journal of Project Management, 26 (2): 124-128.

20. PMI (2018). The Project Manager of the Future: Developing Digital-Age Project Management Skills to Thrive in Disruptive Times. Newtown Square: Project Management Institute.

21. Schoper, Y. G.; Wald, A.; Ingason, H. T.; Fridgeirsson, T. V. (2018). Projectification in Western economies: A comparative study of Germany, Norway and Iceland. International Journal of Project Management, 36: 71- 81.

22. Söderlund, J. and Bredin, K. (2006). HRM in project-intensive firms, changes and challenges. Human Resource Management, 45: 249-265.

23. Sołtysik, M.; Zakrzewska, M.; Sagan, A.; Jarosz, S. (2020). Assessment of Project Manager's Competence in the Context of Individual Competence Baseline. Education Sciences, 10 (146): 2-14.

24. Sydow, R. (2017). Temporary Organizing - The End of Organizations as We Know Them?. Rutgers Business Review, 2: 199-205.

25. Thomas J. and Mengel, T. (2008). Preparing project managers to deal with complexity - advanced project management education. International Journal of Project Management, 26: 304-315.

26. Thomas, J.; Mengel, T. and Andres, N. (2004). Surfing on the edge of chaos developing the master project manager. Proceedings of the PMI global conference 2004 - North America. Newtown Square (PA): Project Management Institute.

27. Turner, J. R. and Huemann, M. M. (2000). Current and future trends in the education on project managers. Project Management, 6: 20-26.

28. Ulrich, D.; Brockbank, W.; Johnson, D.; Sandholtz K.; Younger, J. (2008). HR competencies: Mastery at the intersection of people and business. Alexandria: Society of Human Resource Management.

29. Wong, Z. (2007). Human Factors in Project Management: Concepts, Tools, and Techniques for Inspiring Teamwork and Motivation. San Francisco: Jossey-Bass.

30. Zuofa, T. and Ochieng, E. G. (2021). Investigating Barriers to Project Delivery using Virtual Teams. Procedia Computer Science, 181: 1083-1088. 


\title{
Development of Communication and Team Project Management Competence Elements in a Virtual Environment
}

\author{
Rebeka Danijela Vlahov Golomejić \\ University of Zagreb, Faculty of Economics and Business, Croatia \\ e-mail: rvlahov@efzg.hr
}

\section{Tomislav Rastovski}

University College Algebra, Zagreb, Croatia

e-mail: tomislav.rastovski@gmail.com

\section{Damir Butković}

University of Osijek, Faculty of Economics, Croatia

e-mail: butkovic.db@gmail.com

\begin{abstract}
Given that in today's business environment, an increasing number of organizations base their business on temporary forms of work such as projects, with the aim of achieving greater flexibility and better responses to impulses coming from the market, consequently the demand for competent individuals, who not only have knowledge of the appropriate tools they can use, but also the skills and abilities to deal with the challenges and problems that such a way of working brings is also growing. Moreover, the recent situation and the transition from a physical to a virtual business environment put additional emphasis on the work of virtual project teams, which on the one hand can use new technologies to communicate and manage project progress to work smoothly regardless of where they are at the moment, while on the other hand, they face a completely new dynamic of work, relationships and cooperation among team members. Therefore, significant attention should be paid to project management, as well as the development of necessary competencies in individuals during formal education, and young people should be prepared for the labor market at the latest during their studies by changing the focus from learning significant amounts of data to simulating real situations to thrive in a safe environment without fear of error and to learn from their own experience. This paper examines the perception of the contribution of formal teaching in a virtual environment to the development of communication and team project management competence elements, as well as the challenges they faced in order to form a quality basis for improving the approach to education of students in the field in the period that follows.
\end{abstract}

Key words: competence elements, formal education, communication, teamwork, project management, virtual environment, virtual teams. 